\title{
WII
}

CENTRO STUDI LUCA DAGLIANO

\author{
CENTRO STUDI LUCA D’AGLIANO \\ DEVELOPMENT STUDIES WORKING PAPERS
}

N. 176

September 2003

\section{The Impact of Trade Liberalisation on Enterprises in Small Backward Economies: The Case of Chad and Gabon}

\author{
Giorgio Barba Navaretti* \\ Riccardo Faini** \\ Bernard Gauthier***
}

*University of Milano and Centro Studi Luca d'Agliano

**Italian Ministry of the Economy, University of Brescia, IZA and CEPR

*** HEC Montréal 


\title{
The Impact of Trade Liberalisation on Enterprises in Small Backward Economies: The Case of Chad and Gabon
}

\author{
Giorgio Barba Navaretti \\ University of Milano and Centro Studi Luca d'Agliano \\ Riccardo Faini \\ Italian Treasury, Centro Studi Luca d'Agliano, IZA, and CEPR \\ Bernard Gauthier \\ HEC Montréal
}

March 2003

JEL: 012, 014, F13

KEYWORDS: trade liberalization; enterprise development; output, productivity and export performance

This article is based on a larger study commissioned by the World Bank and the Union Douanière et Économique de l'Afrique Centrale (UDEAC). Michel Sylvain and Loredana Magrì provided excellent research assistance. Under the supervision of the Centre d'Études en Administration Internationale (CETAI) at HEC Montréal, Lise Céré, Danic Ostiguy and Michel Sylvain conducted field interviews. The Centro Studi Luca d'Agliano funded part of the research assistance and logistics for the Italian team. The authors are grateful to Eliana La Ferrara for insightful comments. 


\begin{abstract}
This paper examines the impact of trade and fiscal reforms and of the 1994 devaluation of the CFA franc on enterprise development in Chad and Gabon. These reforms provide a natural experiment to assess the impact of trade liberalisation in countries with a small and backward manufacturing sector. The empirical analysis is based on a new panel data base covering virtually the whole population of manufacturing firms in Chad and Gabon, and containing data spanning from the year before to two years after the reforms. The paper finds that although firms' response to changing incentives was non-negligible, with a shift of output from non tradable to tradable and an increase in productivity, the reform process was unable to generate a virtuous and self-sustained circle, where export expansion brings a generalized productivity increase which in turn feeds on further export growth.
\end{abstract}




\section{INTRODUCTION}

In developing countries, exchange rate devaluation often takes place in conjunction with broad trade and fiscal reforms, the objective being to correct macroeconomic imbalances, improve competitiveness, reduce anti-export biases and strengthen fiscal systems.

CFA countries provide a natural experiment in this regard. The devaluation of the CFA franc in January 1994 was followed by commercial and fiscal reforms in most countries. There has been considerable controversy in the literature as to the effects of such reforms (Guillaumont and Guillaumont, 1995, Devarajan 1996 for the CFA; Winters, 2000 for a more general assessment). We examine here their effects on the manufacturing sector in two small CFA economies, Gabon and Chad. Despite presenting radically different levels of per capita GNP (\$6480 in Gabon and \$978 in Chad in 1997), these countries have a number of common features which are typical of other small backward economies, as evidenced by the weakness of their manufacturing sector, its dependence on the initial transformation of natural resources and on imported inputs and the inward orientation of most of its firms.

To assess the impact, of the devaluation and concomitant trade and fiscal reforms this paper relies on detailed firm-level data spanning the period 1993-1996 for a sample of industrial enterprises in Chad and Gabon. The main finding is that while firms' response to changing incentives was non-negligible, with a marked shift of output from non tradable to tradable and an increase in productivity, the reform process was unable to generate a virtuous and selfsustained circle, where export expansion brings a generalized productivity increase which in turn feeds on further export growth. Indeed, we find no evidence of a positive direct link between export orientation and productivity growth. Productivity growth for exporters was merely due to scale effects rather than export orientation. Because they were exposed to a positive price shock exporters could grow more rapidly. As for non-exporting firms, input costs increased markedly, 
particularly for firms that rely mostly on imported inputs, output growth was often negative, with the fall in size being associated with a decline in productivity. On the basis of these evidences, there are grounds to suspect that the adjustment process may have aggravated the dualism between large exporters and relatively small firms that cater mainly to the domestic markets and are unable (or unwilling) to shift toward foreign markets.

An additional finding is that there was virtually no entry of new firms in the export sector following devaluation and trade reforms. This result is consistent with an earlier study on exports on Cameroon (Tybout et al., 1997).

The article is organized as follows. Section 2 provides an overview of the major shocks and the policy reforms implemented in both countries. In section 3, we use detailed survey data spanning the 1993-96 period, to quantify how the shocks affected relative costs. Section 4 documents and interprets enterprise reaction to the new incentives in terms of resources reallocation, looking at changes in output, productivity and export performance. Section 5 concludes.

\section{The RoOts of the Crisis ANd Policy Responses}

During the eighties and up to the early 1990s, economic performances in Chad and Gabon have been largely unsatisfactory. GDP has been virtually stagnant in Chad and highly vulnerable to the gyrations of oil prices in Gabon. Even after the exploitation of a new and very large oil field, Gabon's growth stagnated at around $2 \%$ in the early 1990s. Production of major export crops such as cotton in Chad and timber in Gabon declined steadily and the resource balance was close to minus $20 \%$ of GDP for Chad and only mildly positive for Gabon. In the latter case, furthermore, government revenues were being eroded as oil exports fell and tax exemptions and evasion became more pervasive. 
The policy environment changed radically in January 1994. Chad and Gabon, together with the other countries in French-speaking Africa, drastically devalued their common currency, the CFA Franc, by $100 \%$ against the French currency to which it was, and still is, pegged.

Furthermore, under the auspices of the World Bank and the IMF, and as other UDEAC countries, Chad and Gabon also introduced a trade and indirect tax reform in order to harmonize the system within the region, with the objective of facilitating exchanges among member countries and making the industrial sector more competitive.

In both countries, decrees were adopted in early 1994 to implement the trade and indirect tax reform. The reform was initially supposed to take effect beginning in January $1995^{1}$ but was brought forward in order to limit the cost-push effects caused by the devaluation. The reform included three main components affecting external trade. First, a unified tariff system, the Common External Tariff (Tarif extérieur commun, TEC), applicable to imports from non-UDEAC countries, was introduced in place of the previous somewhat cumbersome tariff structure. Imports were classified into four categories, with tariffs ranging from 5\% to $30 \%$ (compared with rates of between $0 \%$ and $260 \%$ under the previous system in Gabon and $5 \%$ to $90 \%$ in Chad). Second, a General preferential tariff (Tarif préférentiel généralisé, TPG) was introduced for trade among UDEAC countries. Finally, indirect taxes were also reformed with the elimination of all indirect tax privileges, and the introduction of a value-added tax (VAT) (TCA in Chad).

The 1994 devaluation and the accompanying reforms were quite successful in inducing a substantial depreciation of the real effective exchange rate. In fact, although domestic prices rose by roughly $30 \%$ in the aftermath of the reform, inflation cooled down in the following years, so that the real exchange rate in 1996 was a good 30\% lower than in 1993.

However, aggregate data are typically unable to capture the full constellation of price incentives facing individual firms. Moreover, even if relative prices do change, institutional and

\footnotetext{
$\overline{1}$ January 1, 1994 in Cameroon.
} 
structural weaknesses may severely constrain the capacity of individual firms to respond to the new set of incentives. For Gabon and Chad there are reasons to suspect that this may be indeed the case. In both countries, most manufacturing firms cater exclusively to the domestic markets. Only a handful of firms export a significant share of their output. Moreover, while exportoriented firms are relatively large, they tend to export only a limited fraction of their total production. Under these circumstances, exchange rate devaluation may have only limited effects on the industrial sector unless it triggers either a significant response by existing exporters or a flow of new entries of firms catering to foreign markets. Moreover, the high commodity concentration and the early processing stage of export flows may work to hamper the overall price response. In the next section, therefore, we take a close look at the firm level response drawing on a special survey.

\section{FIRM-LEVEL CHANGES IN RELATIVE PRICES}

Manufacturing firms in Chad and Gabon were surveyed ${ }^{2}$ to collect information on the values and quantities of their five major inputs and five major outputs in the fiscal years 1992-93 and 1995-96. Information was also collected on a set of firms' characteristics, performance and constraints to growth for the period 1992-93 to 1995-96. The three-year period was chosen so as to encompass information preceding the devaluation and trade reforms and the most recent complete fiscal years following the reforms.

\subsection{Nature of the Sample}

2 All types of manufacturing firms were targeted, foreign and domestically owned private and public ownership, large and micro size firms. To qualify for inclusion in the sample, a firm had to be a manufacturing firm and have at least one full time employee in addition to the owner. 
Table 1 presents some basic characteristics of the sample including sectoral composition, average firm size and age.

TABLE 1

Characteristics of the Sample

(percentage of firms)

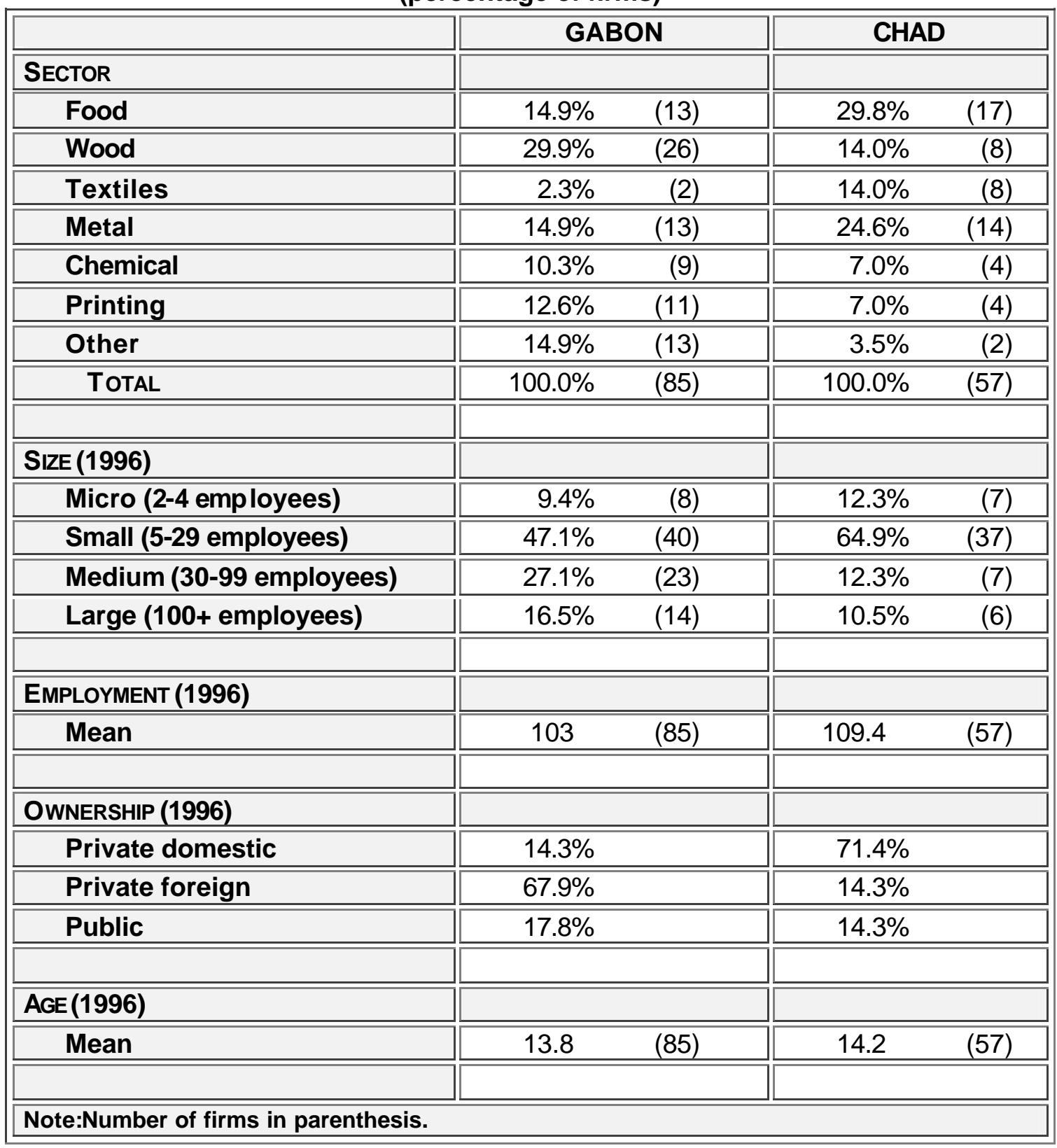


A total of 85 firms were surveyed in Gabon and 57 in Chad. Firms were asked to provide information on their five main inputs and outputs, import intensity and export activities, as well as information on firm characteristics, production, costs, taxes and constraints to growth. ${ }^{3}$

As illustrated in Table 1, the wood sector was the most highly represented sector in our sample in Gabon (29.9\% of the sample), while in Chad the food sector was heavily represented. The textile sector was practically absent from the Gabon sample. When firms are classified in terms of full time employment in 1996, we can see that small firms (5-29 employees) constitute the largest category in both countries (47.1\% in Gabon and $64 \%$ in Chad). Medium-sized firms (30-99 employees) are more prevalent in Gabon (27.1\% compared with $12.1 \%$ in Chad). Foreign ownership was significant in the sample in Gabon.

\subsection{Relative Price Shocks}

Among the 85 firms surveyed in Gabon, only a subset of 44 firms were able to supply complete and credible information on prices and quantities for their main inputs and outputs. In Chad, 34 of the 57 firms surveyed presented complete price data. From this point on, it is this sub-sample of firms that will be used in our analysis.

Using this sub-sample, we constructed unit prices for each product and input ${ }^{4}$. Firmspecific Fischer indexes of the price of each firm's output bundle were then constructed using these product and input specific prices, $\mathrm{P}_{\mathrm{Q}}$, and intermediate goods bundle, $\mathrm{P}_{\mathrm{l}}$, Taking growth

3 Interviews in Gabon were carried in Libreville and its suburbs between May 19 and June 131997. Interviews in Chad were carried out in N'djamena and Moundou between June 9 and 12. The teams of interviewers included people from CETAI at HEC in Montreal and local consultants.

4 Firms had the choice of providing either their direct output price or the value of their various outputs and the number of units produced In such a case, output price was constructed by dividing the value of production by the number of units produced. For example, indexing products by $\mathrm{j}$, we obtained $P_{j t}=V_{j t} / Q_{j t}, j=1$, J. Intermediate input prices were imputed analogously. 
rates in these indexes between the fiscal years 1992-93 and 1995-96, firm by firm, we then obtained the cross-firm distributions of growth rates of relative input prices $\left(P_{1} / P_{Q}\right)$. This threeyear time period covers the devaluation and reforms that took place in 1994 . Fiscal years 1993/94 and 1994/95 have been left out to sharpen the contrast.

TABLE 2

Growth in relative input price

(Cumulative percentages $1992-93$ to 1995-96)

\begin{tabular}{|c|c|c|c|c|c|c|}
\hline & Obs. & Mean & $\begin{array}{l}\text { Standard } \\
\text { deviation }\end{array}$ & $\begin{array}{c}\text { Median } \\
(50 \%)\end{array}$ & Q1 (25\%) & Q3 (75\%) \\
\hline \multicolumn{7}{|l|}{ GABON } \\
\hline Pooled Sample & 44 & 25,33 & 37,56 & 23,45 & 4,56 & 43,10 \\
\hline $\begin{array}{l}\text { Non Exporters } \\
\text { Exporters }\end{array}$ & $\begin{array}{r}38 \\
6 \\
\end{array}$ & $\begin{array}{l}26,73 \\
16,45\end{array}$ & $\begin{array}{l}38,52 \\
32,29\end{array}$ & $\begin{array}{r}24,03 \\
9,54\end{array}$ & $\begin{array}{r}5,55 \\
-7,14\end{array}$ & $\begin{array}{l}47,26 \\
36,25\end{array}$ \\
\hline $\begin{array}{l}\text { Non Importers } \\
\text { Importers }\end{array}$ & $\begin{array}{l}14 \\
30 \\
\end{array}$ & $\begin{array}{l}10,71 \\
32,15 \\
\end{array}$ & $\begin{array}{l}30,35 \\
39,08 \\
\end{array}$ & $\begin{array}{l}17,74 \\
29,75 \\
\end{array}$ & $\begin{array}{l}4,01 \\
5,11 \\
\end{array}$ & $\begin{array}{l}26,54 \\
61,36 \\
\end{array}$ \\
\hline \multicolumn{7}{|l|}{ CHAD } \\
\hline Pooled Sample & 34 & 34,84 & 43,56 & 26,26 & $-0,14$ & 54,54 \\
\hline $\begin{array}{l}\text { Non Exporters } \\
\text { Exporters }\end{array}$ & $\begin{array}{r}33 \\
1 \\
\end{array}$ & $\begin{array}{r}37,17 \\
-42,21 \\
\end{array}$ & $\begin{array}{c}42,02 \\
- \\
\end{array}$ & $\begin{array}{r}32,21 \\
-42,21 \\
\end{array}$ & $\begin{array}{r}7,77 \\
-42,21 \\
\end{array}$ & $\begin{array}{r}54,54 \\
-42,21 \\
\end{array}$ \\
\hline $\begin{array}{l}\text { Non importers } \\
\text { Importers }\end{array}$ & $\begin{array}{r}3 \\
31 \\
\end{array}$ & $\begin{array}{r}-19,51 \\
40,09 \\
\end{array}$ & $\begin{array}{l}20,61 \\
41,66 \\
\end{array}$ & $\begin{array}{r}-14,31 \\
34,21 \\
\end{array}$ & $\begin{array}{r}-42,21 \\
13,71 \\
\end{array}$ & $\begin{array}{l}-1,99 \\
59,28 \\
\end{array}$ \\
\hline
\end{tabular}

We note in Table 2 that the combination of devaluation and commercial policy reforms increased the relative price of inputs for the average and the median firm in both countries. There is a wide range of variation across firms, but the typical increase is about $25 \%$ over the threeyear period in Gabon and 35\% in Chad. Furthermore, more than three-quarters of all firms in both countries experienced at least some increase.

In order to trace differences in incentives among firms with difference in degree of exposure to the foreign markets, the sample is broken down according both to the export 
orientation and the dependence on imported inputs of individual frms. ${ }^{5}$ We note that exportoriented firms did better than non-exporting firms in the sense that the ratio of their input prices to their output prices increased relatively less (16.5\% compared to $26.7 \%$ ) in Gabon and decreased in Chad $(-42 \%)$. This was to be expected, given that exporters should have enjoyed a fairly substantial increase in the CFAF price of their output. However, prudence is required when interpreting the data, due to the small number of exporting firms involved in our sample (only one in Chad).

Furthermore, firms that relied heavily on imported intermediates did quite poorly. In Gabon, imported input intensive firms saw the relative price of their inputs increase by $32.2 \%$ between 1993 and 1996, compared with only 10.7\% for firms relying on domestic inputs. In Chad, the trend was even more pronounced, as imported input intensive firms saw their relative input price rise by $40.1 \%$, while domestic input intensive firms saw a decrease of $19.5 \%$.Summing up, average changes in relative prices are in the expected direction, as they provide favourable incentives towards tradable activities and namely the export sector.

\section{FIRM-LEVEL RESPONSES: OUTPUT AND PRODUCTIVITY GROWTH}

Thus far we have established that the devaluation and reforms did indeed change relative prices at the firm level as intended. In this section, we look at the impact of the reforms on real output and productivity. Among the key objectives of the devaluation and reforms was to shift the pattern of production toward tradable goods and boost productivity. Were these goals achieved?

\footnotetext{
5 A firm is classified as an exporter if it exports any percentage of the value of its output in 1993. A firm is defined as dependant upon foreign inputs when it imports (directly or indirectly) more than $50 \%$ of the value of its inputs in 1993.
} 
Moreover ,

To answer this question, we need to explore carefully the link between changes in relative prices and output and productivity responses. In order to measure firm-level productivity, we begin by defining a cost function as in Tybout, Gauthier, Barba Navaretti and de Melo (1997) and Gauthier, Soloaga and Tybout (2002),

$$
C=f\left(Q, P_{L}, P_{1}, P_{K}, A\right)
$$

where $C$ represents the minimum attainable cost at output level $Q$, productivity level $A$ and a given set of input prices. We make use of a vector of effective (after tax, after tariff) prices (i.e. perceived by firms) for intermediate goods, $P_{\mathrm{I}}$ labour, $\mathrm{P}_{\mathrm{L}}$, and capital, $\mathrm{P}_{\mathrm{K}}$.

Assuming that firms behave optimally, by Shepard's lemma we can obtain the cost minimizing factor demands by taking the first derivatives of the cost function:

(2) $\quad d \ln C=\left(\frac{1}{\eta}\right) d \ln Q+s_{l}\left(d \ln P_{I}\right)+s_{L}\left(d \ln P_{L}\right)+s_{K}\left(d \ln P_{K}\right)+\left(\frac{\partial \ln C}{\partial \ln A}\right) d \ln A$

where $\eta$ is the elasticity of output with respect to cost, i.e., the inverse of returns to scale, and $s_{j}$ denotes the share in total cost of the $\mathrm{j}^{\text {th }}$ factor.

Equation 2 expresses the rate of growth in total cost as the rate of growth in output, weighted by the inverse of returns to scale, plus the share-weighted average rate of growth in input prices, plus the elasticity of cost with respect to time, holding output and prices constant. This last term is a measure of the rate of productivity growth.

The standard decomposition of the sources of growth in cost per unit revenue is obtained by normalizing by the value of output (e.g. Chambers, 1988):

(3)

$$
\begin{aligned}
& d \ln C-d \ln \left(Q P_{Q}\right)=\left(\frac{1}{\eta}-1\right) d \ln Q+s_{I}\left(d \ln P_{l}-d \ln P_{Q}\right)+s_{L}\left(d \ln P_{L}-d \ln P_{Q}\right) \\
& +s_{K}\left(d \ln P_{K}-d \ln P_{Q}\right)+\left(\frac{\partial \ln C}{\partial \ln A}\right) d \ln A
\end{aligned}
$$


where $\mathrm{P}_{\mathrm{Q}}$ is the price of output. This equation can be rewritten in discrete time using a secondorder Tornqvist approximation of this expression. This is done by replacing differentials with difference operators and replacing shares with averages of their beginning-of-period and end-ofperiod values, $\overline{\mathrm{s}}_{\mathrm{j}}{ }^{6}$

$$
\begin{aligned}
& \Delta \ln \mathrm{C}-\Delta \ln \left(\mathrm{QP}_{\mathrm{Q}}\right)=\left(\frac{1}{\eta}-1\right) \Delta \ln \mathrm{Q}+\overline{\mathrm{s}_{\mathrm{I}}}\left(\Delta \ln \mathrm{P}_{\mathrm{I}}-\Delta \ln \mathrm{P}_{\mathrm{Q}}\right)+\overline{\mathrm{s}_{\mathrm{L}}}\left(\Delta \ln \mathrm{P}_{\mathrm{L}}-\Delta \ln \mathrm{P}_{\mathrm{Q}}\right) \\
& +\overline{\mathrm{s}_{\mathrm{K}}}\left(\Delta \ln \mathrm{P}_{\mathrm{K}}-\Delta \ln \mathrm{P}_{\mathrm{Q}}\right)+\left(\frac{\Delta \ln \mathrm{C}}{\Delta \ln \mathrm{A}}\right) \Delta \ln \mathrm{A}
\end{aligned}
$$

where $\Delta$ is the difference operator for period t versus $\mathrm{t}-1$ and the overbars denote cross-period averages of the associated variable. ${ }^{7}$ The interpretation of each term remains the same when discrete changes in logarithms are used. ${ }^{8}$

6 This equation holds if the (unobserved) cost function is a restricted (homothetic, constant returns) translog. Even if these assumptions do not hold, equation 6 provides a second order approximation.

7 To deal with multiple outputs and inputs, we aggregate across the individual commodities using Tornqvist indices. For example, at a given firm, the rate of growth in the output price index is $\Delta \ln P Q=\sum \theta_{j} \Delta \ln \left(P_{j t}^{Q}\right)$, where $P_{j t}^{Q}$ is the price in period $t$ of the $j^{\text {th }}$ product the firm sells, and (suppressing $Q$ superscripts on prices) $\theta_{\mathrm{j}}=.5\left[\left(\frac{\mathrm{P}_{\mathrm{jt}-1} \mathrm{Q}_{\mathrm{jt}-1}}{\sum_{\mathrm{i}=1}^{J} \mathrm{P}_{\mathrm{it}-1} \mathrm{Q}_{\mathrm{it}-1}}\right)+\left(\frac{\mathrm{P}_{\mathrm{jt}} \mathrm{Q}_{\mathrm{jt}}}{\sum_{\mathrm{i}=1}^{J} \mathrm{P}_{\mathrm{it}} \mathrm{Q}_{\mathrm{it}}}\right)\right]$ is the average share of the $\mathrm{j}^{\text {th }}$ product in total revenues in periods $\mathrm{t}$ and $\mathrm{t}-1$. Analogous methods lead to Tornqvist indices of logarithmic changes in the price of inputs and the price of labor.

8 The approximation is nearly exact for small rates of growth. 
Unfortunately, good measures of the returns to scale, ?, are unavailable at the firm level. Therefore, in our calculations, we lump together the output growth effect, $(1 /$ ? -1$)$ ? In $Q$, together with the productivity growth effect to yield a general index of efficiency change. ${ }^{9}$ It is best to think of this scale/productivity term as reflecting all changes in unit costs not accounted for by changes in input prices. ${ }^{10}$ Only under constant returns to scale, ? $=1$, would this term correspond to the standard productivity effect.

Using this decomposition, we can now explore how changing incentives have led to a reallocation of resources and increases in productivity. For this purpose, we estimate simultaneously a supply equation for real output growth and an equation of productivity growth. The supply equation is specified as follows:

$$
\Delta \ln (\mathrm{Q})=\alpha+\beta \Delta \mathrm{C}+\tau \text { DUMEX }_{\mathrm{t}-1}+\rho\left(\text { DUMEX }_{\mathrm{t}-1} \Delta \mathrm{C}\right)+\gamma(\Delta \ln \mathrm{A})+\sigma \mathrm{U}_{\mathrm{t}-1}+\varepsilon_{\mathrm{i}}
$$

where $\triangle \mathrm{C}$ measures the changes in relative costs; DUMEX is a dummy variable that takes a value 1 if the firms exported in 1993 (more than 10\% of their sales for Gabon) and zero otherwise; $\Delta \mathrm{InA}$ is the scale/productivity growth term computed above as a residual of the decomposition of the sources of growth in unit costs; and $U_{t-1}$ is utilization of capacity in 1993.

Output may increase either because of favorable changes in relative prices (output and input prices), or because of an increase in productivity. In general, we expect firms to increase

Also, it should be noted that we take the total rental cost of capital to be $10 \%$ of the replacement cost of the capital stocks or the resale value of the capital stocks, depending on which is reported. (Firms were given a choice in the interviews.) Past values of capital stock are constructed using investment series. Obviously these are crude approximations of the conceptually appropriate measures, but since they only affect the shares of intermediates in total costs, they should not qualitatively change the results on these variables. Their effect on the productivity residual is less innocuous, however, precisely because it is a residual.

10 Our assumption that firms frictionlessly adjust all of their factor stocks is unrealistic. Nonetheless, equation 4 should yield a reasonably good approximation to the effects of relative price changes on unit production costs. However the productivity effect should be viewed with more caution, since it is inferred residually as the difference between a number of imperfectly measured variables. 
real output when productivity rises or when their unit costs decline. We consider two alternative measures of cost changes. The first one is the variation of total long run unit costs, $\Delta \ln \left(C / P_{Q} Q\right)$. It is however suspect of endogeneity, except in the limiting case of constant returns to scale. The second measure is much less prone to these problems, as it uses only the exogenous component of short run unit cost growth, labor and intermediate inputs, $S_{L} \Delta \ln \left(P_{I} / P_{Q}\right)+S_{L} \Delta \ln \left(P_{L} / P_{Q}\right)$. Regarding $U_{t-1}$, we expect that firms already operating at relatively higher capacity levels in 1993 faced tighter constraints when trying to increase output.

We also allow for the possibility that export oriented firms may respond differently to the new economic environment. We do this in two different ways. First, we control for the export status of the firm in the previous year by including an export dummy variable Second, we assess whether exporting firms respond more flexibly to changes in relative prices, by interacting the export dummy and the cost variables.

A key variable on our analysis is productivity. Recall however that our productivity measure also embodies scale effects. It is bound therefore to be endogenous. To control for such effect, we also estimate a simple productivity equation:

(6) $\quad \Delta \ln A=\alpha+\beta F_{t-1}+\sigma[\Delta \ln (\mathrm{Q})]+\varepsilon_{\mathrm{i}}$

where as a dependent variable $(\Delta \ln A)$, we use again the measure of scale/productivity growth computed above. The first two explanatory variables are lagged and represent characteristics of individual firms. $\mathrm{F}$ is a vector of characteristics of the firm at the beginning of the period considered that includes the export dummy, the share of imported inputs, the share of foreign capital, and the employment share of expatriates. The inclusion of real output growth, $\Delta \ln (\mathrm{Q})$, is meant to capture the scale component of our productivity measure. Finally, e is an error term with standard properties. 
The link between productivity and output is in general undetermined. First, it is a function of technology. With increasing returns to scale, higher output may result in higher productivity. Second, this link hinges on the reaction of firms to changing incentives. For instance, firms facing negative price shocks could respond by reducing output and also cutting $x$-inefficiencies and improving productivity. In the case where devaluation brings a positive price shock and higher output, it may nonetheless boost export orientation and expose fims to a more competitive environment. The inclusion of output growth in our equation is meant to capture some of these scale effects.

We estimate the output and productivity growth equations as a system of simultaneous equations to control for the endogeneity of these two variables. Table 3 contains the results of the two-stage least square estimation of the output equation, where we control for the possible endogeneity of productivity growth. Table 4 reports the estimates of the productivity growth equation. 
TABLE 3

Real Output Growth

Econometric Results

\begin{tabular}{|c|c|c|c|c|c|c|c|c|}
\hline $\begin{array}{l}\text { Dependent variable: real } \\
\text { output growth 1993-1996 } \\
\Delta \ln (Q) ?\end{array}$ & \multicolumn{4}{|c|}{ GABON } & \multicolumn{4}{|c|}{ CHAD } \\
\hline $\begin{array}{l}\text { Change in total unit costs } \\
\left(\Delta \ln \left(\mathrm{C} / \mathrm{P}_{\mathrm{Q}} \mathrm{Q}\right)\right.\end{array}$ & - & - & $\begin{array}{l}0.078 \\
(0.964)\end{array}$ & $\begin{array}{l}0.533 \\
(0.776)\end{array}$ & - & - & \begin{tabular}{|l|}
-0.824 \\
$(0.224)$ \\
\end{tabular} & $\begin{array}{l}-0.824 \\
(0.224) \\
\end{array}$ \\
\hline $\begin{array}{l}\text { Change in variable costs } \\
S_{\perp} \Delta \ln \left(P_{I} / P_{Q}\right) 8_{L} \Delta \ln \left(P_{L} / P_{Q}\right)\end{array}$ & $\begin{array}{l}-1.21 \\
(0.029) \\
\end{array}$ & $\begin{array}{l}-1.28 \\
(0.02) \\
\end{array}$ & - & - & $\begin{array}{l}-0.941 \\
(0.018) \\
\end{array}$ & $\begin{array}{l}-0.941 \\
(0.018) \\
\end{array}$ & - & - \\
\hline Dummy Export 1993 & - & $\begin{array}{l}0.47 \\
(0.001) \\
\end{array}$ & - & $\begin{array}{l}0.602 \\
(0.07) \\
\end{array}$ & - & $\begin{array}{l}1.644 \\
(0.00) \\
\end{array}$ & - & $\begin{array}{l}1.72 \\
(0.000) \\
\end{array}$ \\
\hline $\begin{array}{l}\text { Dummy Export } 1993^{*} \\
\text { Change Total Unit Cost }\end{array}$ & - & - & $\begin{array}{l}-1.045 \\
(0.707) \\
\end{array}$ & - & - & - & $\begin{array}{l}-5.932 \\
(0.000) \\
\end{array}$ & - \\
\hline $\begin{array}{l}\text { Dummy Export } 1993^{*} \\
\text { Change Variable Costs }\end{array}$ & $\begin{array}{l}-1.529 \\
(0.015) \\
\end{array}$ & - & - & - & $\begin{array}{l}-3.575 \\
(0.000)\end{array}$ & - & - & - \\
\hline $\begin{array}{l}\text { Utilization of capacity } \\
\text { in } 1993\end{array}$ & $\begin{array}{r}-0.303 \\
(0.446)\end{array}$ & $\begin{array}{l}-0.36 \\
(0.375)\end{array}$ & $\begin{array}{l}-0.079 \\
(0.845)\end{array}$ & $\begin{array}{l}-0.141 \\
(0.768)\end{array}$ & $\begin{array}{l}-0.251 \\
(0.451)\end{array}$ & $\begin{array}{l}-0.2511 \\
(0.451)\end{array}$ & $\begin{array}{l}-0.334 \\
(0.250)\end{array}$ & $\begin{array}{l}-0.334 \\
(0.250)\end{array}$ \\
\hline Productivity growth ('93-96) & $\begin{array}{l}1.258 \\
(0.002)\end{array}$ & $\begin{array}{l}1.35 \\
(0.001)\end{array}$ & $\begin{array}{l}0.82 \\
(0.624)\end{array}$ & $\begin{array}{l}1.424 \\
(0.459)\end{array}$ & $\begin{array}{l}1.384 \\
(0.052)\end{array}$ & $\begin{array}{l}1.384 \\
(0.052)\end{array}$ & $\begin{array}{l}0.14 \\
(0.872)\end{array}$ & $\begin{array}{l}0.14 \\
(0.872) \\
\end{array}$ \\
\hline Number of observations & 44 & 44 & 44 & 44 & 34 & 34 & 34 & 34 \\
\hline
\end{tabular}

2SLS Regression with robust Standard Errors

$P$ values in parenthesis.

TABLE 4

Productivity Growth

Econometric Results

\begin{tabular}{|c|c|c|}
\hline $\begin{array}{lll}\text { Dependent } & \text { variable: } & \text { productivity } \\
\text { growth }(\Delta \ln A) & \end{array}$ & GABON & CHAD \\
\hline Share of imported inputs in 1993 & $\begin{array}{l}0.054 \\
(0.774) \\
\end{array}$ & $\begin{array}{r}-0.195 \\
(0.588)\end{array}$ \\
\hline Dummy Export 1993 & $\begin{array}{r}-0.224 \\
(0.257)\end{array}$ & $\begin{array}{r}-1.072 \\
(0.007)\end{array}$ \\
\hline Share of expatriates on total employment & $\begin{array}{l}0.844 \\
(0.042) \\
\end{array}$ & $\begin{array}{c}0.965 \\
(0.908) \\
\end{array}$ \\
\hline Share of foreign capital & $\begin{array}{c}0.282 \\
(0.074) \\
\end{array}$ & $\begin{array}{r}-0.219 \\
(0.691) \\
\end{array}$ \\
\hline Real output growth 1993-1996 & $\begin{array}{l}0.137 \\
(0.056)\end{array}$ & $\begin{array}{c}0.439 \\
(0.001) \\
\end{array}$ \\
\hline Number of observations & 44 & 34 \\
\hline$R^{2}$ & 0.20 & 0.29 \\
\hline
\end{tabular}

2SLS Regression with robust Standard Errors 
$P$ values in parenthesis

The estimates of the supply equation are as expected for both countries. From the first two columns of the Gabon estimates in Table 3, and from the first two columns of the Chad estimates, we can see that output grows in response to a reduction in unit variable costs. The other four regressions in Table 3 use total unit costs, which turn out not to be statistically significant. This is not particularly surprising, as this measure of costs is a function of output and is likely therefore to be endogenous. More crucially, total unit costs are meant to measure the long-run cost function, which may be an inappropriate determinant of short-run supply behavior. Finally, there may be problems with the measurement of capital costs.

Export orientation is also a significant determinant of output growth. From the first columns of the two countries' regressions in Table 3, we see that exporters are more responsive to price shocks than non-exporters (the export dummy multiplied by the variation in costs is negative). The positive coefficient of the export dummy in the second set of regressions indicates that output growth was faster for exporting firms, even after controlling for price effects. Collinearity problems did not permit to include both variables (DUMEX and DUMEX $\triangle$ C) in the equation. We also see that productivity growth contributes to output growth. Finally, capacity utilization in 1993 bears the expected negative sign, but the coefficient is not statistically different from zero.

Turning to the productivity equation, real output growth plays a statistically significant role in both countries (Table 4). This implies that there are important scale effects which were not accounted for when we computed total factor productivity under the assumption of constant returns to scale. Also, we see that the skill proxies are significant for Gabon only. Moreover, in the case of Gabon, firms with a large share of expatriates on the payroll and a significant foreign ownership show a greater productivity increase. 
Finally, productivity improves less in export oriented firms in Chad. This finding is explained by the performance of one exporter (the only Chad exporter in our sample in 1993), which was rather poor in terms of productivity growth and quite extraordinary in terms of export growth. Even in Gabon, however, the export dummy is not statistically significant. Broadly speaking, we can infer that profit opportunities have induced export-oriented firms to increase output but with no visible productivity impact.

In conclusion, devaluation appears to have favored exporting firms as far as output growth is concerned. Moreover, output growth has triggered productivity growth as firms were able to exploit economies of scale. However, output growth rather than export orientation was the main determinant of productivity growth.

\section{FIRM LEVEL RESPONSE: EXPORTS}

We now take a closer look at the pattern of export expansion. We have seen in the previous section that output grows more in exporting firms. Focusing on Gabon only - the presence of just one exporting firm in Chad makes the analysis much less meaningful - we find that real output growth was significantly larger for exporting firms $(9.3 \%)$ than for the whole sample $(4.2 \%)$. How far has this pattern led to an increasing export orientation of the economy? Real export growth at $15.5 \%$ was substantially larger than real output growth for exporting firms, supporting the notion that firms responded to the new constellation of relative prices by shifting their output toward foreign markets. Indeed, the weighted average export share for Gabon's exporting firms went from $31.2 \%$ to $41.6 \%{ }^{11}$.

Of special interest is to examine to which extent the export growth can be attributed to incumbent firms, the net entry of new firms into the export markets, and the size differences between entering and exiting firms (the turnover effect). Decomposing the sources of export 
growth in this way can cast considerable light on the pattern and the determinants of the export performance. For instance, widespread entry œuld be taken as a signal that firms consider future profits from foreign sales to be large and, at any rate, to outweigh the start-up costs associated with becoming an exporter. It would therefore shed light on the size and credibility of export incentives.

However, if sunk costs are very large, they may deter entry into foreign markets. ${ }^{12}$ Firms that have already adapted their products to foreign markets, established packaging systems and distribution networks and learned to deal with port authorities and custom officials will be more inclined to export than those who have not, all other things being equal. Under such circumstances, incumbent firms will play a paramount role in the expansion of exports. ${ }^{13}$ Entry costs can be expected to be particularly high in Chad and Gabon, especially for the non-African markets. Exporters are specialized in the processing of natural resources or crops for export (cotton, wood). Most other firms produce import substitution goods, not viable for the export market. Switching markets therefore also implies switching products, thus raising entry costs.

To cast light on this issue, we decompose nominal export growth following Sullivan, Roberts and Tybout, 1995, and Tybout, Gauthier, Barba Navaretti and de Melo, 1997 (see the appendix for details). We perform this exercise for Gabon only, given the limited number of exporting firms for Chad.

11 It declines for Chad as a new firm starts exporting in 1996 (only one firm was exporting $100 \%$ of its output in 1993) with a smaller share than the incumbent one.

12 Formal models of export behavior in the presence of start-up costs can be found in Baldwin, 1988, Baldwin and Krugman, 1989, Dixit, 1989, Melitz, 2002).

13 However, incumbent firms may be reluctant to increase their foreign sales. Studying export booms in Morocco, Mexico and Colombia, Sullivan, Roberts and Tybout (1995) found that net entry accounted for more than half the total growth in exports over a five year period. Firms already exporting were either at capacity and unable to export more, or reluctant to redirect output from the domestic market because they faced limited demand for their particular products abroad and/or did not wish to become over-reliant on risky foreign currency revenue sources. 
The results are reported in Table 5. The incumbent effect, the net entry effect and the turnover effect correspond to the three right-hand side terms on the second line of equation (A1) in the appendix, and they sum to nominal export growth.

TABLE 5

Nominal Export Growth Decomposition (Gabon)

\begin{tabular}{||c||c|c||c||c||}
\hline Period & $\begin{array}{c}\text { Nominal } \\
\text { Export } \\
\text { Growth }\end{array}$ & $\begin{array}{c}\text { Incumbent } \\
\text { Effect }\end{array}$ & $\begin{array}{c}\text { Net Entry } \\
\text { Effect }\end{array}$ & $\begin{array}{c}\text { Turnover } \\
\text { Effect }\end{array}$ \\
\hline \hline $1993-96$ & $115,18 \%$ & $115,43 \%$ & $-0,237 \%$ & $-0,0153 \%$ \\
\hline
\end{tabular}

Virtually all export growth is attributable to the incumbents, i.e. to the growth in exports of firms which were already exporters in 1993. The net entry effect is negative, because exiting firms exported more than entering firms. Hwever, their average size was only $2.37 \%$ of the average size of incumbent firms, and hence the contribution of the net entry effect is practically nil. Similarly, the turnover effect accounts for less than $1 \%$ of nominal export growth even though the turnover rate is $25 \%$, as the size difference between entering and exiting firms is negligible. Thus, turnover in the export market is only attributable to small firms, all of similar size.

The export decomposition analysis confirms the previous findings of a study on Cameroon, using the same methodology (Tybout, Gauthier, Barba Navaretti and de Melo, 1997). In Cameroon, as in Chad and Gabon, all nominal export growth was due to incumbents in the export market, and the CFA devaluation failed to generate entry into foreign markets by new exporters. 


\section{Concluding Remarks}

Overall, the main results of the study can be summarised as follows. First, the reforms were successful in changing the incentive structure facing producers. Changes in the real prices of intermediate inputs and of labour have favoured export-oriented firms and penalized firms that cater mainly to the domestic markets and rely heavily on imported inputs.

Second, firms' response to changing incentives has been non-negligible. Our findings show that output shifted toward the exportable sector. Moreover, we also find evidence of substantial productivity gains during the period.

Third, and on a less optimistic note, the reform process was unable to generate a virtuous and self-sustained circle. Regarding exporting firms, we could not find any indications of a positive link between export orientation and productivity growth. It is not the case therefore that by increasing exports and being subject to stronger competitive pressures, firms became more efficient and were thus able to further increase their exports. Our results show that productivity growth is mainly a function of output growth rather than export orientation. Productivity growth increased more among exporters simply because they were subject to a positive price shock and were thus able to grow more rapidly.

Turning to non-exporting firms, devaluation did not come as a blessing. Input costs increased markedly, particularly for firms that rely mostly on imported inputs. Output growth was often negative and led the size of many of these firms to contract in absolute terms. Given that smaller firms may find more difficult to sustain the fixed costs necessary to penetrate into foreign markets, it follows that size will be generally associated with greater export orientation and larger firms will be more prone to cater to foreign markets. To the extent therefore that devaluation and the reform process were associated with a negative price shock and output contraction for nonexporting firms, this may make it harder for these firms face to shift toward export markets. 
Moreover, given that the output contraction is typically associated with a fall in total productivity, this would further compound the task of penetrating foreign markets.

There are grounds to suspect therefore that the adjustment process could aggravate the dualism between large exporters and relatively small firms that cater mainly to the domestic markets and are unable (or unwilling) to shift toward foreign markets. The fact that even at the firm level it was difficult to discern a significant shift toward foreign markets supports such concern. For Gabon, all export growth was associated with incumbent firms, with a previous export tradition. The CFA devaluation failed to generate much entry into foreign markets by new exporters, at least in the short time span analyzed in this study. Public policies should be designed to identify and correct those factors that prevent the growth of small firms toward a more adequate size and that discourage them from turning toward the export markets. Institutional rigidities in the credit and the labor market as well as deficiencies in infrastructures and regulatory constraints are all potential culprits in this respect and may become the objectives for further structural reforms. 


\section{REFERENCES}

Baldwin, Richard E., 1988, "Hysteresis in Import Prices: The Beachhead Effect." American Economic Review 78(4): 773-85.

Baldwin, Richard E. and Paul Krugman, 1989, "Persistent Trade Effects of Large Exchange Rate Changes", Quarterly Journal of Economics 104(4): 635-54.

Chambers, Robert, G., 1988, Applied Production Analysis, New York: Cambridge University Press.

Devarajan, Shanta, 1996, "How Overvalued Was the CFA Franc? Estimates of Real Exchange Rate Misalignement with a Simple General Equilibrium Model", Mimeo, The World Bank.

Devarajan S. and J. de Melo, 1987, "Evaluating participation in African Monetary Unions: a Statistical Analysis of the CFA Zones", World Development, 4, 483-496.

Devarajan S. and J. de Melo, 1990, "Membership in the CFA Zone. Odyssean Journey or Trojan Horse?", PRE Working Paper n. 482, The World Bank, Washington DC.

Devarajan S. and D. Rodrik, 1992, "Do the Benefits of Fixed Exchange Rates Outweigh their Costs? The CFA Zone in Africa", in I. Goldin and A. Winters (eds.), Open Economies: Structural Adjustment and Agriculture, Cambridge University Press.

Dixit, Avinash, 1989, "Entry and Exit Decisions Under Uncertainty", Journal of Political Economy 97(3): 620-38.

Gauthier, B., Soloaga, I and J. Tybout, 2002 "A Firm's Eye View of Commercial Policy and Fiscal Reforms in Cameroon ", The World Bank Economic Review, Vol. 16, No 3, 449-472.

Guillaumont, P. and Guillaumont S., 1995, "Ebranlement et consolidation des fondements des francs CFA", Revue d'Economie du Développement, 3, 87-111.

Melitz, M.J., 2002, "The Impact of Trade on Intra-Industry Reallocations and Aggregate Industry Productivity", Harvard, mimeo

Sullivan, Theresa, James Tybout and Mark Roberts. 1995. "What Makes Exports Boom? Evidence from Plant-Level Panel Data," processed, The World Bank, Washington D.C.

Tybout J., Gauthier B., Barba Navaretti G. and J. de Melo, 1997, "Firm-Level Response to the CFA Devaluation in Cameroon ", Journal of African Economies, Vol. 6, No 1, 3-34.

Winters, A., 2000, "Trade, Trade Policy and Poverty: What Are the Links?", CEPR discussion paper n.2382.

World Bank, 1999, "World Development Indicators", Development Data Centre, Washington D.C. 


\section{APPENDIX \\ Decomposing nominal export growth}

We examine the extent to which the increase in nominal exports between 1993 and 1996 can be attributed to an increase in exports by incumbents, the net entry of new firms into the export market, and the size differences between entering and exiting firms.

$$
\begin{aligned}
& \frac{Q_{t}^{f}-Q_{t-1}^{f}}{Q_{t-1}^{f}}=\sum_{i \varepsilon m}\left(\frac{Q_{i t-1}^{f}}{Q_{t-1}^{f}}\right)\left(\frac{Q_{i t}^{f}-Q_{i t-1}^{f}}{Q_{i t-1}^{f}}\right)+\sum_{i \varepsilon b}\left(\frac{Q_{i t}^{f}}{Q_{t-1}^{f}}\right)-\sum_{i \varepsilon d}\left(\frac{Q_{i t-1}^{f}}{Q_{t-1}^{f}}\right) \\
& =\sum_{i \varepsilon m} S_{i t-1}^{f}\left(\frac{Q_{i t}^{f}-Q_{i t-1}^{f}}{Q_{i t-1}^{f}}\right)+\left(\frac{n_{b t}^{f}-n_{d t-1}^{f}}{n_{t-1}^{f}}\right)\left(\frac{\bar{Q}_{b t}^{f}+\bar{Q}_{d t-1}^{f}}{2 \bar{Q}_{t-1}^{f}}\right)+\left(\frac{\bar{Q}_{b t}^{f}-\bar{Q}_{d t-1}^{f}}{\bar{Q}_{t-1}^{f}}\right)\left(\frac{n_{b t}^{f}+n_{d t-1}^{f}}{2 n_{t-1}^{f}}\right)
\end{aligned}
$$

Here $S_{i t-1}^{f}$ denotes the share of total exports attributable to the $f^{\text {th }}$ plant in year $t 1, n^{f}$ refers to the number of plants that are exporting, $Q_{t}^{f}$ is output sold in foreign markets during year $\mathrm{t}$, and overbars denote temporal averages. In general, i subscripts refer to firms, $m$ subscripts to incumbent firms, b subscripts refer to plants in their first year of exporting, and $d$ subscripts refer to firms that exported at time $\mathrm{k1}$, but ceased doing so at time t. Aggregates without these subscripts refer to the entire set of exporting plants.

We are concerned mainly with the second line of equation (A1). The first term measures the contribution of incumbent exporters to sample-wide export growth. It is a weighted average of the growth in exports among producers who continue to sell abroad $(i \in m)$, the weights being their share in total period t-1 exports. The second term measures the effect of net changes in the number of exporters on growth, i.e. the difference between the number of firms that begin exporting between periods $\mathrm{t}-1$ and $\mathrm{t}(\mathrm{i} \in \mathrm{b})$, and the number of firms that cease exporting during the same period $(i \in d)$. The third term describes the effect on export growth of replacing firms ceasing to export with firms beginning to export. If both groups export the same amount per firm, the turnover effect is nil. On the other hand, if large exporters drop out of foreign markets and are replaced by small exporters, turnover may have a contraction effect. 